\title{
A SZERENCSEJÁTÉKOK TÁRSADALMI ÉS GAZDASÁGI HATÁSAI, VALAMINT A JÁTÉKSZENVEDÉLY PREVENCIÓJÁRA ALKALMAZOTT NEMZETKÖZI GYAKORLATOK
}

A szerencsejátékok társadalmi és gazdasági hatásait és a játékfüggốség kérdéseit elemzi az írás. Mind a hazai, mind a külföldi tanulmányokban találkozni lehet egy ellentétes irányú törekvéssel: egyrészt a szerencsejáték mint az állami bevételek növelésének lehetôsége, másrészt mint az állami kiadások, a szerencsejáték-függôséggel kapcsolatos negatív események felszámolására tett erôfeszítések. A szerzố dolgozatában a téma iránt érdeklódó kutatóknak olyan közgazdasági irányultságú nemzetközi módszertant mutat be, mely a szerencsejáték és annak különbözó fajtáit vizsgálva segít azok gazdasági és társadalmi vonatkozásaiban eligazodni és a különbözó - pozitív és negatív - hatásokat számba venni.

Kulcsszavak: szerencsejátékok, társadalmi hatások, gazdasági hatások, játékfüggőség

Az elmúlt idôszakban egyre jelentôsebb módszertan és vita alakul ki a szerencsejáték társadalmi és gazdasági hatásainak elméleti megközelítéséról. Az egyik kiemelt kérdése ennek a szakmai eszmecserének, hogy a társadalmi hatások és a pénzügyi hatások vizsgálata hogyan vethetố össze, és milyen átfogó modellben lehet ezt kifejezni. Nincs egyöntetú és a szakma által egységesen elfogadott módszertan. Összességében azonban a szerencsejáték megítélése - mind pozitív, mind negatív tényezói - szubjektív elemekkel terhelt, hiszen a társadalmi következményekben jó néhány elem a megfigyeléseken alapul. Ez természetesen nem jelenti azt, hogy ezek a társadalmi, gazdasági elemzések a szerencsejáték vonatkozásában nem folyhatnak megfelelő szakmai színvonalon (Williams et al., 2011).

Ezeknek a tanulmányoknak ${ }^{1}$ inkább az elméleti kereteit és korlátait érdemes tisztázni, amelyek egyrészt a kapott eredmények elfogadhatóságát, másrészt nemzetközi összehasonlíthatóságát is lehetôvé teszik.

A felnőtt lakosság játékszenvedély-előfordulási gyakorisága - az európai országok között $-1,1 \%$
(Olaszország és Spanyolország) és 6,5\% (Észtország) közötti. Míg Magyarországon a problémás szerencsejátékosok aránya 1,9\% (Kun et al., 2012).

Jelen dolgozattal célunk, hogy a téma iránt érdeklődő kutatóknak olyan közgazdasági irányultságú nemzetközi módszertant mutassunk be, mely a szerencsejáték és annak különböző fajtáit vizsgálva segít azok gazdasági és társadalmi vonatkozásaiban eligazodni, és a különbözô - pozitív és negatív - hatásokat számba venni.

\section{A játékszenvedély prevenciójára alkalmazott nemzetközi gyakorlatok}

A szerencsejáték úzésének kóros formáját többféleképpen definiáljuk és kategorizáljuk.

„A problémás játék elnevezés a szerencsejáték-tevékenység azon mintázataira utal, amelyek megzavarják, károsítják a személyes, interperszonális vagy foglalkozásbeli múködést, de e károsodás nem olyan jellegú és mértékú, hogy teljesítené a DSM-IV-TR kritériumait. A patológiás/kóros játékszenvedély a problémás játék- 
Legjobb gyakorlatok a szerencsejáték-függôség megelőzése érdekében

\begin{tabular}{|l|l|}
\hline 1. új kezdeményezések értékelése & 2. csökkentett nyeremények és némi kényelmetlenség \\
\hline 3. foglalkoztatási, oktatási és politikai kezdeményezések & $\begin{array}{l}\text { 4. összekapcsolni ezeket a különbözó oktatási és politikai } \\
\text { kezdeményezéseket (1. 3. pont) }\end{array}$ \\
\hline 5. a szerencsejáték elérhetôségének csökkentése & $\begin{array}{l}\text { 6. a magasabb kockázatú szerencsejátékok fizikai távolsága vagy } \\
\text { redukálása }\end{array}$ \\
\hline 7. jutalomkártyák és bónuszok megszüntetése & 8. játékra jogosultság korlátozása \\
\hline $\begin{array}{l}\text { 9. a dohányzás és az alkoholfogyasztás korlátozása a játék } \\
\text { során (közben) }\end{array}$ & 10. a pénzhez való hozzáférés korlátozása szerencsejáték közben \\
\hline 11. attitúdök és készségek - szerencsejátékosok ismeretei & 12. prevenciós kezdeményezések tartóssága (időtényezó) \\
\hline
\end{tabular}

Forrás: Williams et al. (2012) alapján saját szerkesztés

nál súlyosabb, progresszív és krónikus megbetegedés, amelyet a DSM-IV az impulzuskontroll-zavarok között tárgyal.” (Balázs et al., 2011: 238. old.) Összességében a szerencsejáték-függőt a játékszenvedélye lényegesen befolyásolja életvitelében, számára a játék már nem elsősorban öröm és szórakozás, hanem a legfontosabb tevékenység. A kóros vagy patológiás játékszenvedély mint addiktológiai kórkép előtt azonban a veszélyeztetett és alacsony rizikófaktorú játékosokat is meg kell említenünk. A DSM-IV (az Amerikai Pszichiátriai Társaság diagnosztikai és statisztikai kézikönyve - negyedik kiadás) kritériumok pszichiáterek szakvéleménye alapján, klinikai vizsgálatokra alapozva készült. A közelmúltban kiadásra került a DSM-V (APA, 2013), mely még árnyaltabb diagnosztizálást tesz lehetôvé - és a viselkedészavarok közé ${ }^{1}$ sorolja a játékszenvedélyt.

Shaffer (1996) a „,disordered gambling” kifejezést vezette be a ,problem gambling” helyett a szerencsejátékhoz kapcsolódó valamennyi probléma körülhatárolására, a kóros játékszenvedély mellett a klinikai eseteket is beleértve.

Williams és szerzôtársai (2011) 492 különböző - a szerencsejátékok hatásait vizsgáló - tanulmány öszszevetése után arra a megállapításra jutottak, hogy a leggyakrabban emlegetett gazdasági hatások (minden szerencsejáték-fajtára): az állami bevétel alakulása, a közszolgáltatások megnövekedett szabályozási költsége és a pozitív vagy negatív externális hatások. A legkonzisztensebb társadalmi hatások pedig: a problémás szerencsejátékosok számának megnövekedése, a megnövekedett búnözés, a társadalmi-gazdasági egyenlőtlenség növekedése és további negatív attitúdök a szerencsejátékkal kapcsolatosan (Williams et al,, 2011).

Az elemzés egyik komoly érdeme, hogy egyértelmúen leszögezi, a problémás szerencsejátékosokkal szembeni prevenciós intézkedések a nem problémás szerencsejátékosok számára is némi kényelmetlensé- get okozhatnak, és a bevételek részleges csökkenését is eredményezhetik: „A legtöbb megelőzési kezdeményezés hatékonyságára vonatkozólag akkor lehet tényleges javulást elérni a problémás szerencsejátékosok számában, hogyha ezek a megelôzési politikák és elképzelések a bevételre is hatást gyakorolnak. Ehhez szükséges a potenciálisan veszélyes termékek kivonása vagy elérhetôségük csökkentése, ami mindenképpen a lakosság egy részének is kényelmetlenséget okozhat."(Williems et al., 2011) A közvélemény azonban elfogadja azokat a kormányzati politikákat, amelyek mondjuk a dohányzásra, vagy annak reklámjára vonatkoznak, bár rövid távon ezek is kimutathatóan az adóbevételek csökkenését is eredményezték.

Amerikában elfogadott volt annak idején a lófegyverek használata, az otthoni tartására vonatkozó korlátozások bevezetése, amely egyértelmúen a bưnözésben és az élet elleni búncselekmények visszaszorításában játszhat meghatározó szerepet, mégis elkerülhetetlenné vált, és meg is hozta az eredményét (élet elleni búncselekmények számának csökkenése). Hasonlóképpen a biztonsági öv bevezetése és a sebességkorlátozások sem eredményeztek osztatlan sikert, ugyanakkor közlekedésbiztonsági szempontból ma már mindenki számára elfogadottak.

Ezek a korlátozások valóban szükségesek ahhoz, hogy mérhető és tartós állapotjavulást lehessen elérni. Hasonlóképpen a szerencsejátékok esetén is ilyenfajta megszorítások szükségesek a preventív intézkedések eredményessége érdekében.

A legtöbb kormányzat esetében azonban nem elsôsorban ezek a „lakossági kényelmetlenségek” a meghatározóak, amikor a szerencsejátékok korlátozásáról esik szó, hanem sokkal inkább a közvetlen állami költségvetési bevételkiesés. Azok az országok, melyek kifejezetten megkövetelik a szerencsejátékos helyszínek korlátozását a függőség kialakulásának megakadályo- 
zása érdekében (pl. Németország vagy Svájc), vagy megtiltják azt, hogy a szerencsejátékos kifizetések közvetlenül történjenek (pl. Németország), hatékonyabbak tudnak lenni a preventív intézkedések során. A már alkalmazott legsikeresebb megelózési módokat az 1. táblázatban összesítettük.

Az aktuális magyar szabályozási környezetben, a jelen lévő szerencsejáték-típusok és értékesítési módok ismeretében az 1. táblázat tényezői közül az 5 . és $6{ }^{3}$ gyakorlatilag 2012 végén megvalósult. A táblázatban kiemelt (2., 3., 7., 10., 11., 12.) pontokkal érdemes behatóbban foglalkoznunk. Az oktatáspolitikai kezdeményezések sorában mindenképpen említésre méltó az Ökumenikus Segélyszervezet és a Szerencsejáték Zrt. együttmúködésében négy debreceni általános iskola és középiskola 16 osztályára kiterjedő prevenciós program tervezete, mely 2013 és 2015 között igyekszik az ifjúság bevonásával iskolai képzés és nyári programok keretében a szerencsejáték-szenvedély kialakulását megelőzni.

A bónuszokra vonatkozólag a magyar gyakorlatban nem jellemző, hogy ilyen eszközökkel élnének a szerencsejáték-szervezók, de nem feledkezhetünk meg az internetes nemzetközi sportfogadás-szervezókról, akik viszont már a játékosok agitálása, beszervezése kapcsán különböző bónuszprogramokkal, bónuszkártyákkal igyekeznek megnyerni az új ügyfeleiket.

Nem történt még korábban arra vonatkozó vizsgálat Magyarországon, hogy a kaszinók környezetében találhatunk-e ATM-eket, de a hagyományos lottózók környékén eseti jelleggel fellelhetók bankautomaták. Egyik prevenciós kezdeményezés sem lehet sikeres, ha nem tartalmaz kellő visszacsatolást, korrekciót, folyamatos mérést, és nincsen kellő idôintervallum arra, hogy a programok elérhessék kívánt hatásaikat és a tényleges eredményeket fel lehessen mérni.

Bár igen nehéz megváltoztatni az emberek viselkedését, azonban van néhány jól bevált elmélet, amely elóre vetíti, mikor és hogyan lehet sikeresen befolyásolni az embereket: Theory of Planned Behaviour (Ajzen - Madden, 1986 in: Noar - Zimmerman, 2004), Transtheoretical Model (Prochaska - DiClemente Norcross, 1992 in: Noar - Zimmerman, 2004) és a Health Beliefs Model (Becker, 1974; Janz et al., 2002 in: Noar - Zimmerman, 2004). Annak érdekében, hogy lépéseket tegyenek és változtassanak viselkedésükön: például, ha az információátadás személyes és releváns, ha súlyos következményei vannak annak, ha nem változik a viselkedés, akkor a viselkedésbeli változást viszonylag könnyú elérni. A szerencsejátékok hatásainak mérlegelését sokan, számos eszközzel igyekeztek megtenni, ezek közül válogattunk néhány átfogó modellt és tanulmányt.

\section{A szerencsejátékok társadalmi és gazdasági hatásait értékelő modellek és hatástanulmányok}

Williams és szerzôtársai (2011) a fentebb már hivatkozott, a szerencsejátékok hatásait vizsgáló tanulmányok összevetése során arra a megállapításra jutottak, hogy a pozitív tényezók közül leggyakrabban a költségvetési bevételek és a szerencsejáték-szervezés foglalkoztatásban betöltött szerepe, míg a szerencsejáték negatív hatásait tekintve egyértelmúen a játékszenvedély és a bünözéssel való kapcsolódás a legvitatottabb terület (1. ábra).

\section{1. ábra \\ Az empirikus társadalmi-gazdasági hatástanulmányok által vizsgált területek}

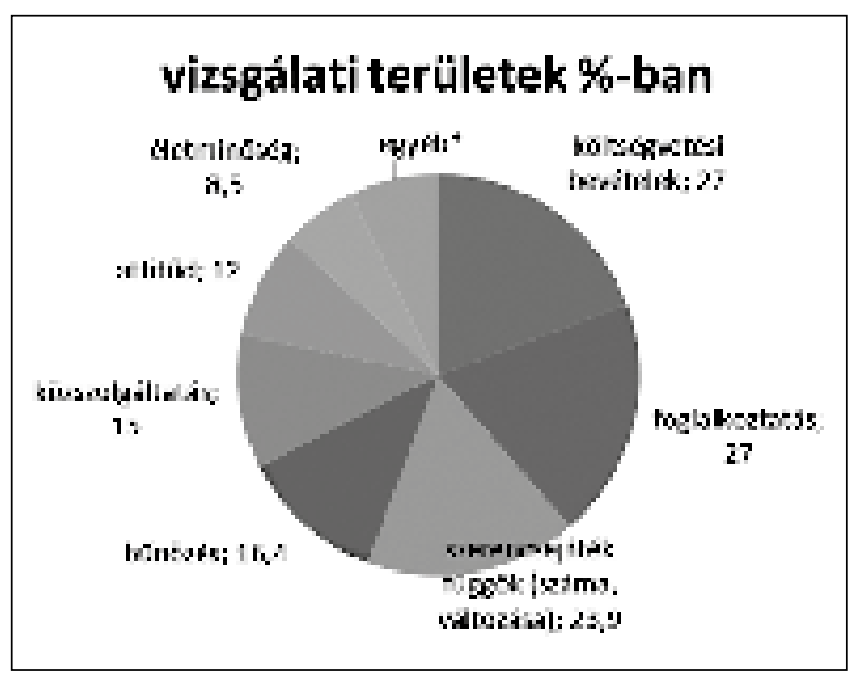

Forrás: Williams et al. (2011) átszerkesztett verzió

* Egyéb: infrastruktúra 7,5\%; társadalmi-gazdasági egyenlőtlenség $7,5 \%$; ingatlan értéke $5,1 \%$; személyi jövedelem $4,8 \%$; szabadidős tevékenységek $4,8 \%$; üzleti kudarc $4,1 \%$; infrastrukturális költségek 3,8\%; üzlet beindulása 3,4\%; szabályozási költségek 2,7\%

2008-ban Anielski és Braatan kísérelt meg egy komplett szocioökonómiai keretrendszert kidolgozni annak érdekében, hogy a szerencsejáték különböző gazdasági és társadalmi hatásait átfogóan értékeljék. Ebben a módszertani leírásban 34 különböző faktort állítottak össze. Céljuk az volt, hogy - elsôsorban Kanadában, de egyébként nemzetközi szinten is - egy univerzális keretet munkáljanak ki, mely használható segítséget nyújt akár a joghatóságok, akár az állami szabályozó szervek számára a szerencsejáték hatásainak kimutatására. Maguk is elismerték, hogy a modelljük túlságosan robusztusra sikerült ahhoz, hogy egyszerúen használható legyen, és a változók és a mutatók vonatkozásában tartalmaz olyanfajta átfedéseket, amik szintén kétségeket ébreszthetnek az azt használni szándékozókban. További nehézségét jelenti a modell alkalmazásának, hogy az egészségügyi, a szociális és 
a gazdasági mutatókban nagyon sok adatra van szükség a szerencsejáték hatásainak kimutatása érdekében. Ugyanakkor az átfedések mellett többszörös hatások, illetve duplikált kockázatok is előfordulnak a keretrendszerükben. Vannak természetesen olyan tényezók is, amelyek számszerúsítése szintén nehézséget okoz, például a jóléti hatások. Szintén saját maguk fogalmazzák meg kritikaként munkájukkal szemben, hogy az ok-okozati összefüggéseknek a beazonosítása kritikus pontja lehet dolgozatuknak (Anielski - Braatan, 2008).

Az egyik módszertani kérdés az, hogy közvetlenül hogyan lehet összehasonlítani a társadalmi hatásokat a pénzügyi és gazdasági vonatkozásokkal annak érdekében, hogy egy átfogó képet kapjunk a szerencsejáték pozitív és negatív elemeinek meghatározására. Ezt egyes tanulmányok elsôsorban a különböző társadalmi hatások pénzbeli értékének becslésével igyekeztek elérni, közülük is a leginkább említésre méltó Grinols 2004-es CBA ${ }^{4}$ típusú megközelítése. Ugyanakkor, míg az egyes költségelemek meghatározása a társadalmi hatásokon belül meglehetôsen egyszerú, például a problémás játékosok kezelése vagy a szerencsejátékkal kapcsolatos búnözés és a fogva tartás ez irányú költsé- gei, sok más költség, illetve társadalmi hatás már nem ilyen egyszerúen azonosítható. Ilyen például az öngyilkosságok, a válások, a társadalmi státus elvesztése, vagy akár a szerencsejátéknak a szabadidő hasznos eltöltésében játszott rekreációs szerepe.

A kaszinók által okozott externális hatásokról elsôként szintén Grinols írt még a 90-es évek elején. Ó fogalmazta meg, hogy a kaszinók, illetve az ott folytatott szerencsejáték elsôdlegesen szociális kérdés, mert amellett, hogy közvetlen előnyöket okoz azáltal, hogy pl. munkahelyeket teremt az adott intézményben, ugyanakkor negatív externáliákat fognak azok viselni, akik a környezetében élnek, pl. a megnövekedett búnözés révén. Úgy vélte, hogy akkor helyes és teljes a felmérés, hogyha a kaszinók gazdasági hatásaiban különbséget teszünk a vállalkozások jövedelmezősége és a szociális jövedelmezőség között. Már ekkor költséghaszon kérdésként fogalmazta meg a kaszinók által okozott eredményeket a háztartások vonatkozásában is, és kísérletet tesz ezeknek a pozitív és negatív externális hatásoknak a számszaki becslésére.

Anielski és Braatan 2. ábrán látható modelljében minél több olyan konkrét tényezót igyekszik számba venni, amelyek a szerencsejátékok következtében költségté-

\section{A szerencsejáték hatásainak teljes pénzügyi-számviteli keretrendszere (Anielski)}

haszon GDF = szerencsejätèk sxemélyes kisdissak szerencsejătékok +

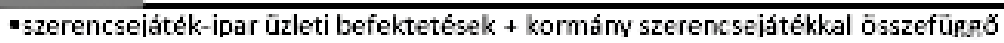
-pxograrrosk kiadiasok + export - impxort nettó

-a problémás szerencsejấtékosoknak a nem problémásokat meğhaladb költséggei •a szerencsejjáték hatására a jövedelmekberı kimutatható vagyani kïlönbségek (pl. Gini-együtthatoj)

\begin{tabular}{|c|c|}
\hline $\begin{array}{l}\text { Egészségés Wellness } \\
\text { költség }\end{array}$ & 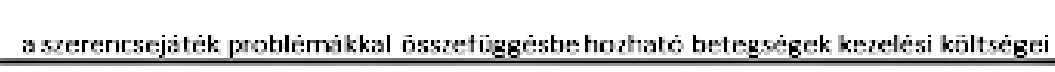 \\
\hline $\begin{array}{l}\text { •szerencscjótćk miatt } \\
\text { •sererencsejáték miatti korai ht }\end{array}$ & 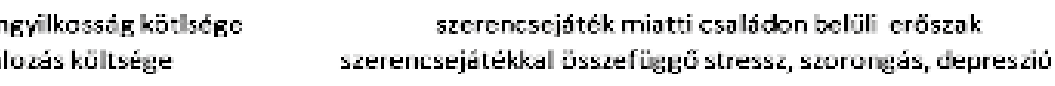 \\
\hline $\begin{array}{c}\text { Gazdasági és Pénzügyi } \\
\text { kältség }\end{array}$ & szerencsejấték miatti kormányati vádelmi kiadésok \\
\hline \multicolumn{2}{|c|}{ 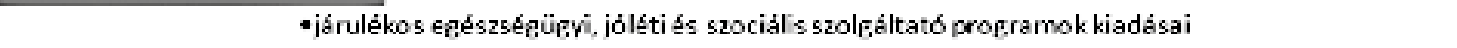 } \\
\hline $\begin{array}{c}\text { Foglalkoztzatás ésaz oktatás } \\
\text { külségei }\end{array}$ & - munkanélküliség és az alulfoglalkoztatottsás \\
\hline kulturảlis költség & immateriális kōltsézek társaclalmi kohẻzió sérülêse a szerencsejaték miatt \\
\hline
\end{tabular}

Forrás: Anielski és Braatan (2008: 64. old.) alapján saját szerkesztés 
nyezóként felmerülnek, és ezt gyakorlatilag a közvetlen szerencsejátékos bevétellel, illetve az állami költségvetési bevétellel állítják szembe. Ez utóbbi módszerrel élt Grinols és Mustard (2001) is, de pusztán a szerencsejátékokból származó állami adóbevételt hasonlították öszsze a patológiás játékfüggókre költött költség éves öszszegével (ehhez a korábbi prevalencia-vizsgálatok alsó értékét szorozták fel a lakosságszámmal). Bár utóbbi módszer meglehetôsen leegyszerúsítette a kérdést, kapott eredményeiket további számításokkal is alátámasztották, és a közel négyszeres erôsségú negatív hatás akkor is markánsan billenti el a szerencsejátékok gazdasági hatásainak mérlegét, ha kalkulálunk Anielskiék fentebbi, differenciáltabb tételeivel. Ugyanakkor a pozitív tényezók között sem számolnak nehezebben számszerúsíthetô elemekkel (szabadidő rekreációs eltöltése, kultúra, turizmus stb.) (3. ábra).

\section{Összegzés}

A szerencsejáték-függőség megelőzésére alkalmazott gyakorlatok, lehetôségek tárházát mutatja be a tanulmány. Mind a hazai, mind a külföldi tanulmányokban találkozhatunk egy ellentétes irányú törekvéssel: egyrészt a szerencsejáték mint az állami bevételek növelésének lehetôsége, másrészt mint állami kiadások, a szerencsejáték-függóséggel kapcsolatos negatív események felszámolására tett erófeszítések.

A veszélyes termékek kivonásával, az elérhetôség redukálásával a bevételek csökkentését érjük el, ugyanakkor a játékfüggés megelőzésében léphetünk előre. Meg kell találni azt az egyensúlyi állapotot, amikor a játékfüggőség miatt szükséges korlátok felállításával eredmények érhetôk el a játékszenvedélyben függốknél, ugyanakkor az állami bevétel sem csökken jelentősen.

Bár diagnosztikai szempontból elhatárolódnak az internetfüggók és a szerencsejáték-függôk egymástól, megfontolásra ajánljuk, hogy - a két érintett kör közötti nagymérvú átfedés miatt - a prevenciós programok kidolgozása során a problémás két csoportot együttesen vizsgáljuk. Napirenden van az internetes szerencsejátékok és sportfogadás szabályozása és a magyarországi elérhetőség feltételeinek törvényi behatárolása. Ez a két momentum szintén szükségessé teszi a szerencsejáték-piac és az internet kapcsolatának újradefiniálását és az új piaci reakciók értékelését.

3. ábra

\section{A szerencsejáték szociális és gazdasági hatásainak keretrendszere}
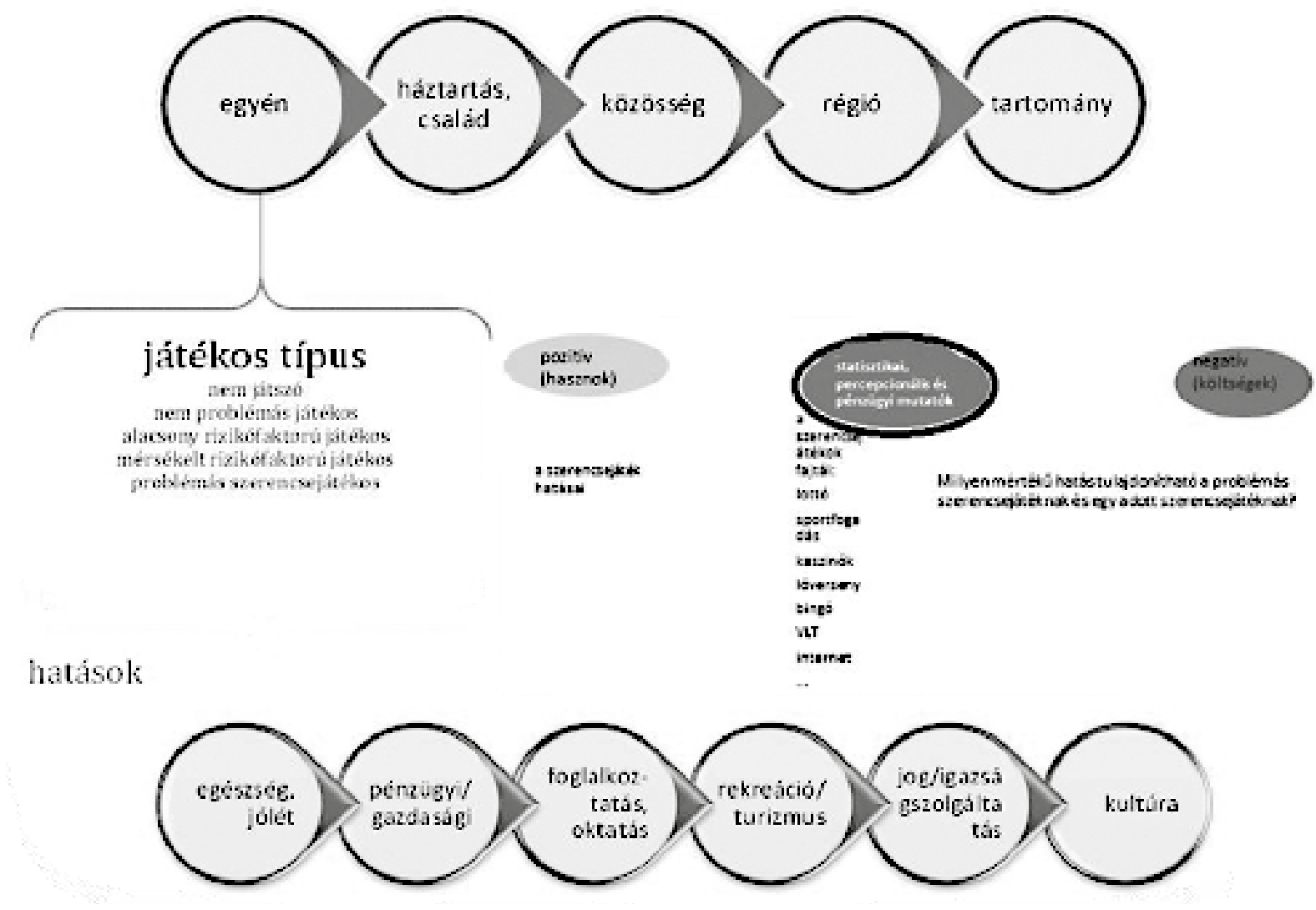

Forrás: Anielski és Braatan (2008: 17. old.) alapján saját szerkesztés 


\section{Lábjegyzet}

${ }^{1}$ A szerencsejáték társadalmi és gazdasági hatásainak vizsgálatára Williamsék mintegy 492 különbözó tanulmányt azonosítottak, melyek közül 293 empirikus vizsgálat volt. Ezek a társadalmi, gazdasági hatástanulmányok túlnyomó többsége 2000 óta született (70\%), de már az 1990-es években is találtak jó néhány tanulmányt, melyek zöme (62\%) az Egyesült Államokban készült. Ezenkívül Kanadában és Ausztráliában fordult elő még nagyobb számban vizsgálat, a bemutatott tanulmányok $16 \%$-a, illetve 8\%-a ezekról a területekról származik. A megvizsgált 492 munka túlnyomó többsége (mintegy 57\%-ban) a kaszinók világát tanulmányozta, a többi tanulmány pedig egyéb szerencsejátékokat, például a lottót $6 \%$, de az internetes szerencsejátékra vonatkozóan csupán e körból 1,4\%-nyi vizsgálat készült. A leggyakoribb témák egyébként az állami bevételek, mintegy 27\% jelenik meg ezekben a munkákban, a foglalkoztatásra vonatkozóan szintén 27\%-nyi a vizsgált terület, a szerencsejáték problémássá válásáról és az ehhez kapcsolódó mutatókról a tanulmányok 24\%-a szól, míg a búnözéssel $16 \%$ foglalkozik. A hatásokra vonatkozó további területeket, úgymint a szabályozási költségek, az életminôségre gyakorolt hatás vagy az adózási vonatkozások, ezeknek a fellelhetố tanulmányoknak kevesebb mint $10 \%$-a veszi elő.

2 A DSM-5-ben a zavar a ,nem szerrel kapcsolatos zavarok” közé tartozik „,szerencsejáték zavar” megnevezéssel.

${ }^{3} 5$. a szerencsejáték elérhetóségének csökkentése, 6. a magasabb kockázatú szerencsejátékok fizikai távolsága vagy redukálása

${ }^{4}$ cost-benefit analysis

\section{Felhasznált irodalom}

Anielski - Braatan (2008): The Socio-Economic Impact of Gambling Framework

APA (2013): DSM-5 referencia-kézikönyv a DSM-5 diagnosztikai kritériumaihoz. Budapest: Oriold és Társai Kiadó és Szolgáltató Kft.

Balázs H. - Kun B. - Demetrovics Zs. (2009): A kóros játékszenvedély típusai. Psychiatria Hungarica 24 (4): p. 238-247.

Grinols, E. (1999): Distance effects in consumption. Review of Regional Studies, 29 (1): p. 63-76.
Grinols, E.L. (2004): Gambling in America - Costs and Benefits. Cambridge: Cambridge University Press

Grinols, E.L. - Mustard, D. (2001): Business profitability versus social profitability: Evaluating the social contribution of industries with externalities, the case of the casino industry. Managerial and Decision Economics, 22 (1-3): p. 143-162. https://www.uleth.ca/ dspace/bitstream/handle/10133/1286/SEIG_FINAL_ REPORT_2011.pdf?sequence=1

Kun B. - Balazs H. - Arnold P. - Paksi B. - Demetrovics Z. (2012): Gambling In Western And Eastern Europe: The Example Of Hungary. Journal Of Gambling Studies, 28 (1): p. 27-46.

Noar, SM. - Zimmerman, R.S. (2004): Health Behavior Theory and cumulative knowledge regarding health behaviors: are we moving in the right direction? Health Education Research, 20 (3): p. 275-290.

Shaffer, H.J. - Martin, R.J. (2011): Disordered gambling: Etiology, trajectory and clinical considerations. Annual Review of Clinical Psychology

Tessényi J. (2012): A szerencsejáték externális hatásai. Társadalomkutatás, 3. szám: p. 291-304.

Seth M. Noar - Rick S. Zimmerman (2004): Health Behavior Theory and cumulative knowledge regarding health behaviors: are we moving in the right direction? Health Education Research, 20 (3): p. 275-290.

Williams, R.J. - West, B.L. - Simpson, R.I. (2012): Prevention of Problem Gambling: A Comprehensive Review of the Evidence, and Identified Best Practices. Report prepared for the Ontario Problem Gambling Research Centre and the Ontario Ministry of Health and Long Term Care. October 1, 2012. http://hdl.handle.net/10133/3121

Williams, R. - Stevens, R. (2011): The Social and Economic Impacts of Gambling; Final Report prepared for the Canadian Consortium for Gambling Research. March 11, 2011. URI:http://hdl.handle.net/10133/1286 Date: 2011-03-11 (letöltés: 2013. május 29.)

\section{E S Z Á M U N K S Z E R Z Ö I}

Dr. Kenesei Zsófia, egyetemi docens, Budapesti Corvinus Egyetem; Janecskó Eszter, marketingmunkatárs, ITF Consulting; Dr. Csillag Sára PhD. fóiskolai docens, Budapesti Gazdasági Fớiskola, egyetemi adjunktus, Budapesti Corvinus Egyyetem; Dr. Fekete István, tudományos munkatárs, Budapesti Corvinus Egyetem; Jenei István, egyetemi adjunktus, Budapesti Corvinus Egyetem; Losonci Dávid, tudományos segédmunkatárs, Budapesti Corvinus Egyetem; Dr. Heidrich Balázs, egyetemi docens, Budapesti Gazdasági Főiskola; Kása Richárd, tudományos munkatárs, Budapesti Gazdasági Fóiskola; Dr. Tessényi Judit PhD., közgazdász, régióvezető, Szerencsejáték Zrt.; Dr. Felméry Zoltán, tudományos segédmunkatárs, Nemzeti Közszolgálati Egyetem; Dr. Papp József, egyetemi docens, Budapesti Corvinus Egyetem 